\title{
Bahasa Sunda sebagai Bahasa Ibu di Provinsi Jawa Tengah: Studi Data Sensus Penduduk 2010
}

\author{
Suyanto \\ Fakultas Ilmu Budaya, Universitas Diponegoro \\ suyanto@undip.ac.id
}

\begin{abstract}
Central Java Province is a speech community of Javanese language, but Sundanese language as a mother tongue in residents the Central Java area bordering with West Java. Because of Central Java as a speech community the Javanese langage, it's as one subject of local content in this region. For residents who speak Sundanese as mothertongue, this is a difficulty in itself. It is important for us to discuss. This paper aims to analyze the use of Sundanese as a mother tongue and its implications in language teaching policy in the Province of Central Java. The data in this study were collected by literature study technique with data source, that is,TheCitizenship, Ethnicity, Religion, and Every day language Indonesia Population: Result of Population Census2010. Data analysis using statistics descriptive and descriptive qualitative.Data from the 2010 Population Census shows that 578,164 people of Central Java (age 5 and above) use Sundanese as the mother tongue of a total of 29,671,375. The number of Sundanese speakers in Central Java is spread across 14 districts in two districts, namely Brebes and Cilacap. The presence of Sundanese speakers in Central Java is due to two factors: 1) migration factors and 2) non-migration factors. Number of Sundanese speakers due to migration factor 109,428 and non-migration factors amounted to 468,736 .
\end{abstract}

Keywords: Sundanese speakers, migration, non-migration, Central Java, West Java.

\section{Intisari}

Provinsi Jawa Tengah merupakan masyarakat tutur bahasa Jawa, namun penduduk di daerah Jawa Tengah yang berbatasan dengan Jawa Barat menggunakanan bahasa Sunda sebagai bahasa sehari-hari (bahasa ibu). Karena Jawa Tengah sebagai masyaratakat tutur bahasa Jawa, maka bahasa Jawa sebagai salah satu mata pelajaran muatan lokal di wilayah ini. Bagi penduduk yang berbahasa ibu bahasa Sunda, hal ini merupakan kesulitan tersendiri. Karena itulah, hal ini penting untuk kita diskusikan. Paper ini bertujuan menganalisis pemakaian bahasa Sunda sebagai bahasa sehari-hari (bahasa ibu) dan implikasinya dalam kebijakan pengajaran bahasa daerah di Provinsi Jawa Tengah. Data dalam studi ini dikumpulkan dengan teknik studi pustaka dengan sumber dataKewarganegaraan, Suku Bangsa, Agama, dan Bahasa Sehari-hari Penduduk Indonesia: Sensus Penduduk2010. Analisis data menggunakan statistik deskriptif dan deskriptif kualitatif.Data hasil Sensus Penduduk 2010 menunjukkan bahwa578.164 jiwa penduduk Jawa Tengah (umur 5 tahun ke atas) menggunakan bahasa Sunda sebagai bahasa ibu dari total 29.671.375. Jumlah penutur bahasa Sunda di Jawa Tengah tersebar di 14 kecamatan dalam dua kabupaten, yakni Brebes dan Cilacap. Keberadaan penutur 
bahasa Sunda di Jawa Tengah karena dua faktor yaitu 1) faktor migrasi, dan 2) faktor non-migrasi. Jumlah penutur bahasa Sunda karena faktor migrasi 109.428 jiwa. Sementara itu, jumlah penutur bahasa Sunda karena faktor non-migrasi sebesar 468.736 jiwa.

Kata Kunci: penutur bahasa Sunda, migrasi, non-migrasi, Jawa Tengah, Jawa Barat.

\section{Pendahuluan}

Bahasa adalah cermin budaya masyarakat penuturnya serta merangkum identitas diri atau masyarakatnya sebagai sebuah etnis (bangsa). Karena hal itu, budaya suatu etnis tidak dibatasi oleh batas-batas wilayah administratif pemerintahan, namun bisa melintasi batas tersebut. Karena hal itu, di daerah-daerah perbatasan dijumpai kantong-kantong komunitas budaya (Darheni, 2011), seperti di Provinsi Jawa Tengah yang berbatasan dengan Jawa Barat (Kabupaten Brebes dan Cilacap) dijumpai masyarakat atau komunitas penutur bahasa Sunda yang sebenarnya secara administratif mereka sebagai penduduk Provinsi Jawa Barat, tempat hidup dan digunakannya bahasa sunda sebagai bahasa ibu.

Bahasa Sunda merupakan bahasa pertama atau bahasa ibu bagi sebagian besar etnik Sunda. Bahasa ini tidak hanya tersebar di Jawa Barat, tetapi juga di luar Jawa Barat (Darheni, 2011), salah satunya di Provinsi Jawa Tengah. Berdasarkan hasil Sensus Penduduk 2010 (BPS, 2010), pemakaian bahasa Sunda sebagai bahasa sehari-hari di Provinsi Jawa Tengah sebesar 578.164 jiwa atau 1,78\% dari jumlah penutur bahasa Sunda yang tersebar secara nasional (BPS, 2010). Angka tersebut menempati peringkat ke-3 pemakaian bahasa Sunda terbanyak sebagai bahasa sehari-hari, sedangkan peringkat pertama pemakaian bahasa Sunda tentu ada di Jawa Barat, menyusul kemudian, peringkat kedua pemakaian bahasa Sunda terbanyak ada di Provinsi Banten.Jumlah pemakaian bahasa Sunda di Provnisi Jawa Tengah masih jauh lebih sedikit jika dibandingkan dengan pemakaianbahasa Jawa yang merupakan bahasa ibu di Jawa Tengah. Jumlah pemakaian bahasa Jawa di Provinsi Jawa Tengah sendiri sebesar 28.401.022 jiwa atau 41,74 \% dari jumlah penutur bahasa Jawa sebagai bahasa seharihari secara nasional. 
Dalam penelitian ini, pemakaian bahasa Sunda di Provinsi Jawa Tengah dianalisis berdasarkan dua faktor, yakni 1) faktor migrasi, dan 2) faktor non-migrasi. Faktor migrasi menjadi faktor yang melatarbelakangi eksistensi penutur bahasa Sunda di Provinsi Jawa Tengah karena pengaruh migrasi, baik migrasi seumur hidup maupun migrasi risen (lima tahun yang lalu). Penutur bahasa Sunda karena faktor migrasi tersebar di berbagai daerah di Jawa Tengah. Lalu, faktor non-migrasi menjadi faktor yang melatarbelakangi adanya penutur bahasa Sunda yang tersebar di kantong-kantong bahasa Sunda di Provinsi Jawa Tengah. Kantong-kantong bahasa Sunda di Jawa Tengah terdapat di beberapa kecamatan di Kabupaten Brebes dan Kabupaten Cilacap.

Penelitian ini bertujuan untuk mengkaji pemakaian bahasa Sunda sebagai bahasa sehari-hari di Jawa Tengah menggunakan pendekatan demografilinguistik (makro). Fokus kajian dalam penelitian ini ialah penutur bahasa Sunda di Provinsi Jawa Tengah. Variabel penelitian ini dibagi menjadi dua, yakni 1) struktur demografilinguistik sebagai variabel statis yang berupa jumlah, komposisi, dan distribusipenutur bahasa Sunda untuk menjelaskan faktor non-migrasi dalam pemakaian bahasa Sunda di Provinsi Jawa Tengah, 2) Proses atau variabel dinamis yang dalam penelitian ini berupa faktor migrasi.

\section{Metode Penelitian}

\section{Pendekatan}

Penelitian ini menggunakan pendekatan demografilinguistik, terutama demografilinguistik makro, yakni studi secara umum menggunakan data sekunder tentang penutur bahasa di suatu wilayah tertentu. Demografilinguistik memfokuskan kajiannya pada struktur dan proses demografilinguistik di suatu wilayah tertentu. Struktur demografilinguistik meliputi jumlah, komposisi, dan persebaran penutur bahasa dalam satu wilayah tertentu. Sementara itu, proses demografilinguistik meliputi kelahiran, kematian, dan migrasi penutur bahasa. Struktur bersifat statis sedangkan proses bersifat dinamis (Suyanto, 2011 dan 2017).

Dalam artikel ini, kajian difokuskan pada aspek struktur demografilinguistik, baik yanga berkaitan dengan migrasi penutur bahasa, dalam hal ini penutur bahasa 
Sunda ke Jawa Tengah maupun non-migrasi, yakni penduduk Jawa Tengah di perbatasan Jawa Barat yang menggunakan bahasa Sunda sebagai bahasa ibu (komunikasi sehari-hari di rumah dan dalam ranah ketetanggaan atau ruang publik. Kajian demografilinguistik sampai saat merupakan suatu kajian yang relative baru, terutama bagi linguis Indonesia. Hal ini disebabkan istilah ini sebagai sebuah disiplin baru dalam pengkajian bahasa belum populer. Tulisan Suyanto (2011) misalnya, yang merupakan awal kajian demografilinguistik di Indonesia, masih menyebutnya dengan istilah sosiolinguistik dengan pendekatan makro tentang jumlah penutur bahasa (Indonesia) yang menggunakan data sekunder (data Sensus Penduduk (SP) 1980). Tulisan tersebut mengkaji jumlah penutur bahasa Indonesia dikaitkan dengan variabel tempat tinggal (desa-kota dan pulau), jenis kelamin, dan tingkat pendidikan. Studi tersebut menjelaskan bahwa penutur bahasa di daerah perkotaan lebih mampu menggunakan bahasa Indonesia daripada penuturbahasa di pedesaan. Sementara itu, distribusi secara kepulauan penutur bahasa Indonesia didominasi oleh pulau Sumatera, walaupun secara absolut (jumlah), penutur bahasa Indonesia terbanyak tinggal di pulau Jawa. Dari segi jenis kelamin, komposisi penutur bahasa Indonesia lebih didominasi oleh laki-laki daripada perempuan (Suyanto, 2011).

Dalam tulisan Suyanto (2017) sudah secara jelas dikatakan bahwa demografilinguistik sebagai sebuah ancangan dalam studi bahasa. Studi tersebut memfokuskan pada dinamika jumlah penutur bahasa di Provinsi Lampung. Berdasarkan data SP 2010, jumlah penduduk di Provinsi Lampung lebih dari 55 persen sebagai penutur bahasa Jawa dalam komunikasi sehari-hari. Sementara itu, bahasa Indonesia sebagai sarana komunikasi sehari-hari menempati urutan kedua $(22,74$ persen) dan urutan ketiga adalah bahasa Sunda yang hampir delapan persen dari kesekluruhan jumlah penduduk Lampung. Tabel di bawah tidak secara eksplisit menyebut jumlah penutur bahasa Lampung, namun, dalam tabel tersebut diinformasikan bahwa jumlah penutur bahasa "lain" mencapai 13 persen lebih. Jumlah itulah yang sebenarnya merupakan penutur bahasa Lampung. Data tersebut dapat ditriangulasi menggunakan jumlah penduduk Lampung berdasar asal suku bangsa. Data SP 2010 menunjukkan 
bahwa jumlah penduduk Lampung yang berasal dari suku Lampung sebanyak 13,56 persen, sedangkan penutur bahasa lain sebesar 13,66 persen (Suyanto, 2017).

\section{Tahap-tahap Penelitian}

Tahap-tahap dalam penelitian, terutama penelitian bahasa dilakukan melalui tiga tahap yaitu tahap pengumpulan data, tahap analisis data, tahap penyajian hasil analisis data (Sudaryanto, 1988). Ketiga tahap tersebut merupakan langkah yang dilakukan dalam studi ini dan dijelaskan di bawah satu per satu.

Tahap Pengumpulan Data

Pengumpulan data dalam penelitian ini menggunakan teknik studi pustaka secara mendalam. Data diperoleh dari laporan hasil Sensus Penduduk (SP) 2010 yang dipublikasikan oleh Badan Pusat Statistik (BPS). Selain itu, data juga diperoleh dari data sensus penduduk di dua kabupaten yakni Kabupaten Brebes dan Cilacap. Selain data tersebut, studi pustaka juga dilakukan dengan cara menelaah penelitian-penelitian terdahulu terkait pemakaian bahasa Sunda di Provinsi Jawa Tengah.

Tahap Analisis Data

Data yang telah terkumpulkan selanjutnya dianalisis dengan teknik analisis statistik deskriptif dan deskriptif kualitatif. Teknik ini menguraikan dan menjelaskan perhitungan statistik hasil Sensus Penduduk 2010, selanjutnya melalui perhitungan yang dihasilkan itu diuraikan melalui penjelasan deskriptif kualitatif sehingga mampu menerangkan kajian demografilinguistik, terutama pemakaian bahasa Sunda sebagai bahasa sehari-hari di Provinsi Jawa Tengah yang berkaitan dengan faktor migrasi dan non-migrasi.

\section{Tahap Penyajian Hasil Analisis Data}

Penyajian hasil analisis data penelitian ini menggunakan teknik informal. Teknik tersebut menjelaskan hasil analisis data melalui kata-kata yang mampu menerangkan hasil analisis secara keseluruhan dengan mudah dipahami. 


\section{Penutur Bahasa Sunda di Jawa Tengah berdasar Faktor Migrasi dan Non-migrasi}

Berdasarkan data Sensus Penduduk (SP) 2010 yang dilakukan oleh Badan Pusat Statistik (BPS), jumlah penduduk di Jawa Tengah sebesar 32.382.657 jiwa. Jumlah penduduk yang tergolong berusia 5 tahun keatas sejumlah 29.671.375 jiwa. Sebesar $1,78 \%$ dari jumlah penduduk Jawa Tengah yang berusia di atas 5 tahun menggunakan bahasa Sunda sebagai bahasa sehari-hari atau sejumlah 578.164 jiwa. Di Jawa Tengah, Jumlah tersebut menempati peringkat ke-2sebagai bahasa yang memiliki jumlah penutur terbanyak. Lalu, secara nasional, penutur bahasa Sunda di Provinsi Jawa Tengan menempati peringkat ke-3 sebagai pemakai bahasa Sunda terbanyak setelah Provinsi Jawa Barat dan Provinsi Banten.

Bahasa Sunda bukanlah bahasa ibu di Provinsi Jawa Tengah. Keberadaan penutur bahasa Sunda di Provinsi Jawa Tengah dipengaruhi oleh dua faktor. Faktor tersebut ialah faktor non-migrasi dan faktor migrasi. Pengelompokan tersebut dilakukan berdasarkan kenyataan bahwa pemakaian bahasa Sunda sebagai bahasa sehari-hari di Provinsi Jawa Tengah banyak dijumpai di wilayah-wilayah yang secara administratif berbatasan dengan Provinsi Jawa Barat, seperti beberapa wilayah di Kabupaten Brebes dan Kabupaten Cilacap.

\section{Faktor Migrasi}

Mobilitas penduduk dibedakan menjadi dua yaitu mobilitas vertikal dan horizontal. Mobilitas vertikal adalah perubahan status sosial ekonomi sesorang dari status yang lebih rendah ke status yang lebih tinggi atau sebaliknya. Sementara itu, mobilitas penduduk horizontal atau biasa dikenal sebagai migrasi penduduk geografis adalah gerak penduduk yang melintas batas wilayah tertentu menuju ke wilayah yang lain dalam periode waktu tertentu (Mantra, 2015:172). Unit wilayah bisa mulai dari tingkat dukuh (dusun) hingga Negara bahkan benua, sedangkan unit waktu bisa mulai dari enam jam hingga seumur hidup.

Batasan waktu migrasi bagi migran dalam studi ini ditetapkan minimal enam bulan, artinya seseorang dikatakan migran jika tinggal ditempat baru atau berniat tinggal ditempat baru paling sedikit enam bulan lamanya. Keterangan bahwa seorang pernah pindah atau tidak adalah dengan melihat pada adanya perubahan tempat tinggal 
seseorang. Perbedaan tempat tinggal inilah yang digunakan sebagai proksi migrasi (BPS, 2010). Dalam studi ini, migrasi dibedakan menjadi dua yaitu migrasi seumur hidup dan migrasi risen.

Pemakaian bahasa Sunda sebagai bahasa sehari-hari di Jawa Tengah juga dipengaruhi oleh faktor migrasi penduduk, khusunya migrasi masuk ke Jawa Tengah dari Jawa Barat. Migran yang berasal dari Jawa Barat dianggap menggunakan bahasa Sunda sebagai bahasa sehari-hari mengingat bahasa Sunda merupakan bahasa ibu di Jawa Barat. Berikut penjelasan migrasi seumur hidup dan migrasi risen di Jawa Tengah: Migrasi Seumur Hidup

Migrasi seumur hidup mencerminkan keadaan perpindahan yang terjadi sejak lama. Seseorang dikategorikan sebagai migran seumur hidup jika provinsi tempat lahir berbeda dengan provinsi tempat tinggal sekarang atau tempat tinggalnya saat pencacahan (BPS, 2010).

Tabel 1. Jumlah Penduduk Migran dan Non-Migran di Provinsi Jawa Tengah

\begin{tabular}{|c|c|c|}
\hline Kategori Penduduk & $\begin{array}{l}\text { Jumlah Penduduk } \\
\text { (Jiwa) }\end{array}$ & $\begin{array}{l}\text { Jumlah Penduduk } \\
\text { (\%) }\end{array}$ \\
\hline Penduduk Migran & 906.714 & 2,8 \\
\hline Penduduk Non-Migran & 31.475 .943 & 97,2 \\
\hline Jumlah & 32.382 .657 & 100 \\
\hline
\end{tabular}

Sumber: BPS, 2011.

Berdasarkan data hasil Sensus Penduduk 2010, sebesar 9,1\% penduduk merupakan migran masuk seumur hidup yang lahir di Jawa Barat sehingga jumlah penduduk migran asal Jawa Barat adalah sebesar $=9,1 \%$ x 906.714 jiwa $=82.510,97$ (82.511) jiwa,seperti tercantum pada Tabel 2, dan sisanya merupakan penduduk migran seumur hidup dari daerah lain. 
Tabel 2. Jumlah Penduduk Migran (Seumur Hidup) Asal Jawa Barat ke Jawa Tengah

\begin{tabular}{|c|r|r|}
\hline Kategori Penduduk & \multicolumn{1}{|c|}{$\begin{array}{c}\text { Jumlah } \\
\text { Penduduk } \\
\text { (Jiwa) }\end{array}$} & $\begin{array}{c}\text { Jumlah } \\
\text { Penduduk } \\
(\%)\end{array}$ \\
\hline Penduduk migran seumur hidup asal Jawa Barat & 82.511 & 9,1 \\
\hline Penduduk migran seumur hidup asal daerah lain & 824.203 & 90,9 \\
\hline Jumlah & 906.714 & 100 \\
\hline
\end{tabular}

Sumber, BPS, 2011.

\section{Migrasi Risen}

Migrasi risen lebih mencerminkan keadaan perpindahan terkini dimana perpindahannya menunjukan keadaan lima tahun yang lalu. Sesorang dikategorikan migran risen jika tempat tinggal lima tahun yang lalu berbeda dengan tempat tinggal sekarang atau tempat tinggal saat pencacahan (sensus). Keterangan mengenai migrasi ini diperoleh secara langsung dari penduduk berumur 5 tahun keatas yang mempunyai tempat tinggal tetap (BPS, 2010).

Tabel 3. Migrasi Risen Masuk ke Provinsi Jawa Tengah Usia di atas 5 Tahun

\begin{tabular}{|l|r|}
\hline \multicolumn{1}{|c|}{ Migrasi Risen } & \multicolumn{2}{|c|}{ Jumlah } \\
\hline Presentase migrasi risen di atas 5 tahun (\%) & 1,0 \\
\hline Jumlah migrasi risen di atas 5 tahun (jiwa) & 296.714 \\
\hline $\begin{array}{l}\text { Jumlah keseluruhan penduduk Jawa Tengah di } \\
\text { atas 5 tahun (jiwa) }\end{array}$ & 29.671 .375 \\
\hline
\end{tabular}

Sumber, BPS, 2011.

Berdasarkan data hasil Sensus Penduduk 2010, sebesar 11,4\% merupakan migran masuk risen yang lahir di Jawa Barat. Jadi, jumlah migran risen masuk Jawa Tengah yang lahir di Jawa Barat sejumlah 33.825,396 (33.825) jiwa. Data tersebut juga menunjukan bahwa jumlah penduduk Jawa Tengah usia 5 tahun keatas yang merupakan migran risen lahir di Jawa Barat dan menggunakan bahasa Sunda sebagai bahasa sehari-hari sejumlah 33.825 . 
Jadi, dapat disimpulkan bahwa penutur bahasa Sunda sebagai bahasa sehari-hari di Provinsi Jawa Tengah berdasarkan faktor migrasi dibedakan menjadi dua yaitu jenis migrasi seumur hidup dan migrasi risen. Penghitungannya berdasarkan data migrasi masuk dari Provinsi Jawa Barat ke Provinsi Jawa Tengah.

Tabel 4. Jumlah Penutur Bahasa Sunda di Jawa Tengah Berdasarkan Faktor Migrasi

\begin{tabular}{|l|r|}
\hline \multicolumn{1}{|c|}{$\begin{array}{c}\text { Jenis Migrasi Masuk (dari } \\
\text { Jawa Barat ke Jawa Tengah) }\end{array}$} & $\begin{array}{c}\text { Jumlah Penduduk Jawa Tengah usia 5 tahun ke } \\
\text { atas dan berbahasa Sunda sebagai bahasa sehari- } \\
\text { hari (jiwa) }\end{array}$ \\
\hline Migrasi Seumur Hidup & 75.603 \\
\hline Migrasi Risen & 33.825 \\
\hline Jumlah & 109.428 \\
\hline
\end{tabular}

Sumber, BPS, 2011.

\section{Faktor Non-migrasi}

Berdasarkan hasil Sensus Penduduk 2010 menyebutkan bahwa terdapat 578.164 jiwa penduduk Jawa Tengah yang menggunakan bahasa Sunda sebagai bahasa sehari-hari. Setelah menghitung jumlah penutur bahasa Sunda di Jawa Tengah berdasarkan faktor migrasi, maka dapat diketahui pula jumlah penutur bahasa Sunda di Provinsi Jawa Tengah berdasarkan faktor non-migrasi.

Tabel 5. Perbandingan Jumlah Penduduk Jawa Tengah yang Berbahasa Sunda Berdasarkan Faktor Migrasi dan Non-Migrasi

\begin{tabular}{|l|l|r|}
\hline \multicolumn{2}{|c|}{$\begin{array}{c}\text { Penduduk Jawa Tengah berbahasa Sunda sebagai } \\
\text { bahasa sehari-hari }\end{array}$} & $\begin{array}{c}\text { Jumlah Penduduk } \\
\text { (Jiwa) }\end{array}$ \\
\hline \multirow{2}{*}{ Faktor Migrasi } & Migrasi Seumur Hidup & 75.603 \\
\cline { 2 - 3 } & Migrasi Risen & 33.825 \\
\hline \multirow{2}{*}{ Faktor Non-Migrasi } & Kabupaten Brebes & 468.736 \\
\cline { 2 - 3 } & Kabupaten Cilacap & 578.164 \\
\hline \multicolumn{2}{|l|}{ Jumlah Penutur Bahasa Sunda di Jawa Tengah } \\
\hline
\end{tabular}

Sumber, BPS, 2011.

Faktor non-migrasi dalam penelitian ini menjadi variabel statis yang berkaitan dengan penutur bahasa Sunda di Provinsi Jawa Tengah, khususnya Kabupaten Brebes dan 
Kabupaten Cilacap. Berdasarkan data pada Tabel 5 maka diketahui bahwa jumlah penduduk Jawa Tengah yang menggunakan bahasa Sunda sebagai bahasa sehari-hari sebesar 468.736 jiwa. Jumlah penutur bahasa Sunda tersebut tersebar di dua kabupaten di Provinsi Jawa Tengah, yaitu Kabupaten Brebes dan Kabupaten Cilacap. Beberapa wilayah (kecamatan) di kedua kabupaten itu disebut wilayah borderland yang mana merupakan daerah perbatasan administratif antara Jawa Tengah dan Jawa Barat yang juga menjadi kantong bahasa Sunda di Jawa Tengah. Bahasa akan sulit dipetakkan berdasarkan wilayah adminsitratif. Bahasa adalah cermin budaya masyarakatnya serta merangkum identitas dirinya sebagai sebuah etnis (bangsa). Namun, budaya suatu etnis tidak dibatasi oleh batas-batas wilayah administratif pemerintahan (Darheni, 2011).

Penelitian ini tidak dapat menguraikan pembagian jumlah penutur bahasa Sunda di Jawa Tengah tiap wilayah (kecamatan) di Kabupaten Brebes dan Cilacap. Hal itu disebabkan tidak tersedianya data penutur bahasa Sunda di Jawa Tengah hingga pencacahan tingkat kecamatan. Data penutur bahasa Sunda sebagai bahasa sehari-hari di Jawa Tengah hanya terbatas pada tingkat provinsi saja. Simpulannya, 468.736 jiwa penduduk Provinsi Jawa Tengah yang menggunakan bahasa Sunda sebagai bahasa sehari-hari tersebar di Kabupaten Brebes dan Kabupaten Cilacap. Untuk menjelaskan karakteristik pemakaian bahasa Sunda di wilayah tersebut maka berikut uraian faktor non-migrasi masing-masing kabupaten.

Sebanyak 1.736.331 jiwa penduduk Kabupaten Brebes tersebar di 17 kecamatan yang ada. Dari 17 kecamatan yang ada, hanya terdapat 7 Kecamatan yang menggunakan bahasa Sunda sebagai bahasa sehari-hari. Ketujuh kecamatan tersebut terletak di sebelah barat Kabupaten Brebes yang berbatasan langsung dengan Jawa Barat. Ketujuh kecamatan yang masyarakatnya sebagian besar menggunakan bahasa Sunda atau biasa disebut dengan Bahasa Sunda Brebes, meliputi:
a) Kecamatan Banjarharjo,
b) Kecamatan Bantarkawung,
c) Kecamatan Ketanggungan,
d) Kecamatan Larangan,
e) Kecamatan Losari, 
f) Kecamatan Salem,

g) Kecamatan Tanjung.

Sementara itu, Kabupaten Cilacap merupakan daerah pertemuan budaya Jawa Banyumasan dengan budaya Sunda (Priangan Timur) karena berbatasan langsung dengan Provinsi Jawa Barat. Sebagian penduduk Kabupaten Cilacap bertutur dalam bahasa Sunda, terutama di kecamatan-kecamatan yang berbatasan dengan Jawa Barat, disebabkan pada masa lalu wilayah kabupaten ini adalah bagian dari Kerajaan Galuh. Beberapa kecamatan di Kabupaten Cilacap yang penduduknya berbahasa Sunda ialah: Kecamatan Dayeuhluhur, Wanareja, Kedungreja, Patimuan, Majenang, Cimanggu, dan Karangpucung.

\section{Simpulan}

Penutur bahasa Sunda di Provinsi Jawa Tengah berdasarkan hasil Sensus Penduduk 2010 sejumlah 578.164 jiwa. Keberadaanya dipengaruhi oleh dua faktor, yaitu 1) faktor migrasi, dan 2) faktor non-migrasi.

Faktor migrasi menjadi faktor yang melatarbelakangi adanya penutur bahasa Sunda di Provinsi Jawa Tengah karena pengaruh migrasi, baik migrasi seumur hidup, maupun migrasi risen. Penutur bahasa Sunda karena faktor migrasi tersebar di Jawa Tengah tanpa adanya batasan pasti di mana saja persebarannya dengan jumlah penutur sebesar 109.428 jiwa.

Faktor nonmigrasi menjadi faktor yang melatarbelakangi adanya penutur bahasa Sunda yang tersebar di kantong-kantong bahasa Sunda di Provinsi Jawa Tengah dengan jumlah penutur sebesar 468.736 jiwa. Kantong bahasa Sunda di Jawa Tengah terdapat di beberapa kecamatan di Kabupaten Brebes dan Kabupaten Cilacap. Beberapa kecamatan di Kabupaten Brebes yang menjadi kantong bahasa Sunda di antaranya ialah Kecamatan Banjarharjo, Bantarkawung, Ketanggungan, Larangan, Losari, Salem, dan Tanjung, sedangkan beberapa kecamatan di Kabupaten Cilacap di antaranya ialah Kecaman Dayeuhluhur, Wanareja, Kedungreja, Patimuan, Majenang, Cimanggu, Karangpucung. 


\section{Daftar Pustaka}

Badan Pusat Statistik. 2011. Hasil Sensus Penduduk 2010: Kewarganegaraan, Suku Bangsa, Agama, dan Bahasa Sehari-hari Penduduk Indonesia. Jakarta: BPS Indonesia.

2011. Hasil Sensus Penduduk 2010: Migrasi Internal Penduduk Indonesia. Jakarta: BPS Indonesia.

Borbely, Anna. 2000. "The Process and the Factors of Language Shift and Maintenance: A Sociolinguistics Research in the Romanian Minority in Hungary". http://elib.rss.cz

Borin, Lars. 2009. Linguistic resources for the languages of the world. Språkbanken, Dept. of Swedish Language, University of Gothenburg GF summer school, 26 August.

BPS Kabupaten Brebes. 2011. Kabupaten Brebes dalam Angka Tahun 2011. Brebes: Badan Pusat Statistik Kabupetn Brebes.

BPS Kabupaten Cilacap. 2012. Kabupaten Cilacap dalam Angka Tahun 2012. Cilacap: Badan Pusat Statistik Kabupetn Cilacap.

Darheni, Nani. 2011. Bahasa Sunda Perbatasan (Borderland) di Wilayah Kabupaten Cilacap, Jawa Tengah: Primodialisme Masyarakat Perbatasan Jawa Tengah dan Jawa Barat. Bandung: Balai Bahasa Bandung.

Kesuma, Tri Mastoyo Jati. 2007. Pengantar (Metode) Penelitian Bahasa. Yogyakarta: Carasvatibooks.

Mantra, Ida Bagoes. 2015. Demografi Umum, Cetakan XVII. Yogyakarta: Pustaka Pelajar.

Musgrave, Simon and John Hajek. 2010. "Sudanese Languages in Melbourne: Linguistic Demography and Language Maintenance". Selected Papers from the 2009 Conference of the Australian Linguistic Society, edited by Yvonne Treis \& Rik De Busser. http://www.als.asn.au.

Samuel, Jerome. 2008. Kasus Ajaib Bahasa Indonesia: Pemoderenan Kosakata dan Politik Peristilahan. Penerjemah Dhani Saraswati Wardhani. Jakarta: KPG (Kepustakaan Populer Gramedia).

Suyanto. 2011. "Dinamika Jumlah Penutur Bahasa Indonesia :Studi Data Sensus Penduduk" 1980. Kajian Sastra, Vol. 35 No. 1, hal. 55-67.

Suyanto dan Mujid FA. 2017. "Pemakaian Bahasa Jawa di Provinsi Lampung Bedasar Data Sensus Penduduk 2010”. NUSA, Vol. 12. No. 3 Agustus. 